\title{
Tooth Mobility Due to Chronic Periodontitis with Hypertension: A Cross Sectional Study
}

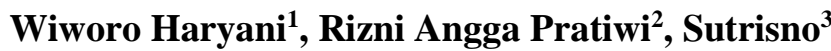 \\ ${ }^{1}$ Associate Professor, Department of Dental Health, Poltekkes Kemenkes Yogyakarta, Indonesia \\ ${ }^{2}$ Dental Therapist, Dental Polyclinic DR. Moewardi General Hospital, Surakarta, Indonesia \\ ${ }^{3}$ Assistant Professor, Department of Dental Health, Poltekkes Kemenkes Yogyakarta, Indonesia
}

\begin{abstract}
One of the non-communicable diseases that is becoming a very serious health problem today is hypertension which is known as the silent killer. Periodontal disease is an inflammatory disease associated with a small number of gram-negative anaerobic bacteria. These gram-negative anaerobic bacteria have the opportunity to become systemic diseases, including diabetes mellitus, cardiovascular disease and blood clotting problems. Cardiovascular diseases include coronary heart disease and hypertension. This study aims to analysis the relationship between tooth mobility due to chronic periodontitis and hypertension. Methods: analytic observational research with cross sectional design. The study was carried out on patients at the Dental Polyclinic of Dr. Moewardi Hospital Surakarta. The research sample was taken by purposive sampling technique, as many as 84 people. The independent variable in this study was tooth mobility due to chronic periodontitis, while the dependent variable was hypertension. Collecting data using a questionnaire, the OHI-S index examination sheet and the Community Periodontal Index (CPI). Data analysis using Kendall's tau test. Results: the relationship between tooth mobility due to chronic periodontitis and hypertension showed that the p-value was $0.011(\mathrm{p}<0.05)$ Conclusion: there was a significant relationship between tooth mobility due to chronic periodontitis and hypertension.
\end{abstract}

KEYWORDS: Chronic Periodontitis, Hypertension, Tooth Mobility.

\section{INTRODUCTION}

Hypertension or high blood pressure is a chronic medical condition in which there is an increase in blood pressure in the arteries that exceeds a certain threshold value. Hypertension is a condition of blood pressure equal to or exceeding $140 \mathrm{mmHg}$ systolic and equal to or exceeding $90 \mathrm{mmHg}$ diastolic. Hypertension is one of the most common diseases in Indonesia. The prevalence of hypertension from the results of measurements of the Indonesian population aged over 18 years was 34.1\% [1-3].

Some people with hypertension are not aware that they have hypertension and only find out after getting a health check. Sometimes hypertension itself is a disease that does not cause symptoms. One of the non-communicable diseases that is a very serious health problem today is hypertension which is known as the silent killer [4,5].

Periodontitis is one of the most common periodontal diseases suffered by Indonesian people after dental caries. Data from basic health research in 2018 showed that in Indonesia cases of periodontitis reached 74.1\% [3]. Periodontitis is an inflammation of the supporting tissues of the teeth, caused by microorganisms and can cause progressive damage to the periodontal ligament, alveolar bone and accompanied by pocket formation. This disease is also the biggest cause of tooth loss in adults aged 30 years and over. Bone damage due to periodontitis can cause teeth to become loose. Tooth mobility is one of the symptoms of periodontal disease which is characterized by loss of attachment and vertical bone damage [6-8].

Sumali et al in a study found that systolic blood pressure increased progressively with the severity of periodontal disease and that there was a possible rational relationship between hypertension and periodontal disease based on findings showing that both are inflammatory processes. Periodontal disease is an inflammatory disease associated with a small number of gram-negative anaerobic bacteria. These gram-negative anaerobic bacteria also have the opportunity to become three systemic diseases, including diabetes mellitus, cardiovascular disease and blood clotting problems. Cardiovascular diseases include coronary heart disease and hypertension [9].

Another study by Shamsuddin et al revealed that hypertension is associated with increased serum CRP (C-reactive protein) levels and a study observed that higher serum CRP levels were found among periodontitis patients. However, the study conducted by 


\section{International Journal of Current Science Research and Review}

ISSN: 2581-8341

Volume 04 Issue 12 December 2021

DOI: 10.47191/ijesrr/V4-i12-20, Impact Factor: 5.825

IJCSRR@ 2021

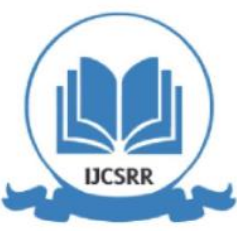

www.ijesrr.org

Shamsuddin et al did not find a significant relationship between hypertension and the severity of chronic periodontitis, based on a limited sample size [10].

\section{METHODOLOGY}

This research is an analytical observational study with a cross-sectional approach. The research was conducted at the Dental Polyclinic of Dr. Moewardi Hospital Surakarta. The sampling technique used purposive sampling technique, as many as 84 people. The independent variable in this study was tooth mobility due to chronic periodontitis and the dependent variable was hypertension.

The collection of data on tooth mobility was measured using a diagnostic tool and data for hypertension was measured using a sphygmomanometer. Data analysis was carried out using the data analysis of this study using the Kendall's tau test with a significance value of $\mathrm{p}<0.05$ because it is looking for a correlation or relationship between 2 variables with a nominal scale.

\section{RESULT}

Table 1. Frequency distribution of respondent characteristics

\begin{tabular}{|lll|}
\hline $\begin{array}{l}\text { Respondent } \\
\text { characteristics }\end{array}$ & \multicolumn{2}{l|}{ Total } \\
\cline { 2 - 3 } & $\mathrm{n}$ & $\%$ \\
\hline Gender & & \\
\hline Male & 34 & 40.5 \\
\hline Female & 50 & 59.5 \\
\hline Total & 84 & 100 \\
\hline Age & & \\
\hline $17-25$ years & 6 & 7.1 \\
\hline $26-45$ years & 32 & 38.1 \\
\hline $46-60$ years & 46 & 54.8 \\
\hline Total & 84 & 100 \\
\hline
\end{tabular}

Table 1 shows that the number of female respondents was more than male, namely 50 respondents (59.5\%) and the 46-60 years age group was 46 respondents $(54.8 \%)$.

Table 2. Frequency distribution based on tooth mobility and hypertension

\begin{tabular}{|lll|}
\hline \multirow{2}{*}{ Variable } & \multicolumn{2}{l|}{ Total } \\
\cline { 2 - 3 } & $\mathrm{n}$ & $\%$ \\
\hline Tooth mobility & & \\
\hline Yes & 69 & 82.1 \\
\hline No & 15 & 17.9 \\
\hline Total & 84 & 100 \\
\hline Hypertension & & \\
\hline Yes & 42 & 50.0 \\
\hline No & 42 & 50.0 \\
\hline Total & 84 & 100 \\
\hline
\end{tabular}

Table 2 shows that the majority of respondents who experience tooth mobility are 55 respondents $(65.5 \%)$ and respondents with hypertension and non-hypertension are balanced as many as 42 respondents (50\%).

Table 3. Correlation of tooth mobility with hypertension

\begin{tabular}{|lll|} 
Kendall's tau test & $\mathrm{p}$-value & Correlation coefficient \\
\cline { 2 - 3 } & 0.011 & 0.280 \\
\hline
\end{tabular}




\section{International Journal of Current Science Research and Review}

ISSN: 2581-8341

Volume 04 Issue 12 December 2021

DOI: 10.47191/ijesrr/V4-i12-20, Impact Factor: 5.825

IJCSRR@ 2021

WwW.ijesrr.org

The results of the statistical test in table 3 show that $\mathrm{p}=0.011$ which means $\mathrm{p}<0.05$ with a correlation coefficient of 0.280 .

\section{DISCUSSION}

Based on the results of the study, it can be concluded that the number of female respondents is more than male, namely 50 female respondents $(59.5 \%)$. Women are more likely to have their teeth checked when there are problems with their teeth. In line with research on periodontitis by Sugiarti \& Santik a study of 90 respondents with 52 women (57.8\%) [11].

The frequency distribution based on age criteria shows that the most respondents are aged 46-60 years as many as 46 respondents (54.8\%). Respondents aged 46-60 years can be classified into early and late old age or young elderly. This is in line with Sazali's research which states that the level of needs of someone aged $>45$ years increases due to the aging process. The aging process will cause various physical-biological, psychological and social problems [12].

The results showed that most of the respondents had loose teeth, as many as 69 respondents (82.1\%). Tooth mobility as a result of damage to the periodontal tissue, and can become more severe if the respondent does not immediately go to the dentist to check his teeth. Tooth mobility is one of the symptoms of periodontal disease which is characterized by loss of attachment and vertical bone destruction. Immobility can be caused by damage to the bone that supports the teeth, trauma from occlusion and the expansion of inflammation from the gingiva to the deeper supporting tissues and pathological processes of the jaw [13].

The results showed that respondents who had high blood pressure or hypertension and did not have hypertension were balanced. So that $50 \%$ of patients who are considered to have hypertension need to be studied further by a specialist in internal medicine to control their blood pressure so as not to cause danger in the future. Increased blood pressure that lasts for a long time (persistent) can cause damage to the kidneys (kidney failure), heart (coronary heart disease) and brain (causing stroke) if not detected early and receive adequate treatment. Hypertension can cause various complications [14].

Based on the statistical data analysis test with the Kendall's tau correlation, the p-value of $0.011(\mathrm{p}<0.05)$ means that there is a relationship between tooth mobility and hypertension in chronic periodontitis patients at the dental polyclinic of Dr. Moewardi Hospital Surakarta. Tooth loss due to chronic periodontitis can manifest in blood pressure. Periodontal disease can lead to dysfunction which in turn increases the risk of hypertension [15].

\section{CONCLUSION}

Based on the results of the study, it can be concluded that there is a significant relationship between tooth mobility due to chronic periodontitis and hypertension.

\section{CONFLICT OF INTEREST}

The author hereby declares no conflict of interest

\section{ETHICAL CLEARANCE}

The study was conducted after obtaining approval from the Ethics Committee of the Health Polytechnic of the Ministry of Health Yogyakarta No. e-KEPK/POLKESYO/0641/X/2020

\section{REFERENCES}

1. Appel LJ, Wright Jr JT, Greene T, Agodoa LY, Astor BC, Bakris GL, et al. Intensive blood-pressure control in hypertensive chronic kidney disease. N Engl J Med 2010;363:918-29.

2. Alhawari HH, Al-Shelleh S, Alhawari HH, Al-Saudi A, Aljbour Al-Majali D, Al-Faris L, et al. Blood pressure and its association with gender, body mass index, smoking, and family history among university students. Int $\mathbf{J}$ Hypertens $2018 ; 2018$.

3. Kemenkes RI. Hasil utama riskesdas 2018. Jakarta Kemenkes RI 2018.

4. Weber MA, Schiffrin EL, White WB, Mann S, Lindholm LH, Kenerson JG, et al. Clinical practice guidelines for the management of hypertension in the community: a statement by the American Society of Hypertension and the International Society of Hypertension. J Hypertens 2014;32:3-15.

5. Ekpenyong CE, NE U, Akpan EE, Samson TK. Double burden, non-communicable diseases and risk factors evaluation in 


\section{International Journal of Current Science Research and Review}

ISSN: 2581-8341

Volume 04 Issue 12 December 2021

DOI: 10.47191/ijesrr/V4-i12-20, Impact Factor: 5.825

IJCSRR@ 2021

sub-Saharan Africa: The Nigerian experience. Eur J Sustain Dev 2012;1:249.

6. Quamilla N. Stres dan kejadian periodontitis (kajian literatur). J Syiah Kuala Dent Soc 2016;1:161-8.

7. Inaba H, Amano A. Roles of oral bacteria in cardiovascular diseases-from molecular mechanisms to clinical cases: Implication of periodontal diseases in development of systemic diseases. J Pharmacol Sci 2010;113:103-9.

8. Azodo C, Erhabor P. Management of tooth mobility in the periodontology clinic: An overview and experience from a tertiary healthcare setting. African J Med Heal Sci 2016;15:50.

9. Sumali R, Masulili SLC, Lessang R, Sukardi I. Peran Hipertensi terhadap Mediator Peradangan dalam Perkembangan Penyakit Periodontal dan Jantung Koroner. Maj Kedokt Gigi Indones 2010;17:68-73.

10. Shamsuddin SN, Ahmad A, Taib H, Mohamad WMW. Hypertension and its association with the severity of chronic periodontitis: a preliminary study. Arch Orofac Sci 2015;10:3-9.

11. Sugiarti T, Santik YDP. Kejadian periodontitis di Kabupaten Magelang. Higeia (Journal Public Heal Res Dev 2017;1:97108.

12. Sazali H. Tingkat Kebutuhan Perawatan Periodontal Pada Lansia Di Panti Wredha Dharma Bhakti Surakarta Tahun 2016 2016.

13. Oktawati S, Astuti LA. Perawatan Bedah Flap Periodontal Pada Periodontitis Kronis: Sebuah Laporan Kasus. J Ilm AsSyifaa 2014;6:98-106.

14. Zaenurrohmah DH, Rachmayanti RD. Hubungan pengetahuan dan riwayat hipertensi dengan tindakan pengendalian tekanan darah pada lansia. Stroke 2017;33:67.

15. Leong X-F, Ng C-Y, Badiah B, Das S. Association between hypertension and periodontitis: possible mechanisms. Sci World J 2014;2014.

Cite this Article: Wiworo Haryani, Rizni Angga Pratiwi, Sutrisno (2021). Tooth Mobility Due to Chronic Periodontitis with Hypertension: A Cross Sectional Study. International Journal of Current Science Research and Review, 4(12), 1766-1769 